Stawomir Zatwardnicki Papieski Wydział Teologiczny Wroctaw

\title{
Wizja teologii w wypowiedziach papieża Franciszka
}

\section{THE VISION OF THEOLOGY IN POPE FRANCIS' STATEMENTS}

The Holy Father does not avoid themes which should interest theologians. In the apostolic constitution Veritatis gaudium he directly expresses his understanding of the role of theology at the present phase of the Church's mission. The author of the article arranges Francis' statements in the context of evangelization widely understood: starting from proclaiming the kerygma, through the social dimension of the Gospel, ending up with the service of accompanying the whole mankind. Then the author deals with the Pope's understanding of the Tradition in its relation to the modern reality, of the orthodoxy that is not separated from orthopraxis, as well as of the theological sources (loci theologici). The author finishes by suggesting the most important issues which require further theological studies. The issue of the deepened apprehension of orthodoxy is particulary worthy of attention.

Key words: Pope Francis, orthodoxy, orthopraxis, theology, evangelization, Argentine liberation theology, loci theologici, Tradition, the preferential option for the poor, Veritatis gaudium.

„It seems clear that Pope Francis ha s not yet been understood, at least in the English-speaking world, on a theological level”. Tę ocenę wyrażoną w czasopiśmie „Nova et Vetera” w 2014 roku można by 
również odnieść do świata polskiej teologii AD 2018 . Sytuacja ta niepokoi, tym bardziej, że Franciszek nie tylko że nie stroni od tematów, które żywo winny interesować teologów, ale również wprost wyraził swoje rozumienie teologii na obecnym etapie misji Kościoła publikując konstytucję apostolską Veritatis gaudium². Autor niniejszego tekstu stawia sobie skromne zadanie uszeregowania wypowiedzi papieskich dotyczących teologii, a następnie podsumowania ich oraz wskazania zagadnień teologicznych domagających się dalszych badań.

\section{Teologia w służbie ewangelizacji}

\section{Znamię kerygmatyczne}

Odnowę studiów kościelnych widzi Ojciec Święty w perspektywie powołania Kościoła do głoszenia Ewangelii. To, co stało się swego rodzaju „programem” zaproponowanym przez papieża całemu Ludowi Bożemu, dotyczy również teologów, od których oczekuje się adekwatnej reakcji na wkroczenie Kościoła w nowy etap misji ${ }^{3}$. Zachęta wyrażona przez Franciszka w adhortacji Evangelii gaudium, „posiada programowe znaczenie i ważne konsekwencje” i dotyczy wezwania do permanentnego podążania „drogą duszpasterskiego i misyjnego nawrócenia” (EG 25). Ten „wybór misyjny” miałby skutkować przyjęciem „stylu ewangelizacyjnego" obejmującego wszelkie działanie Kościoła,

Theology of Pope Francis u podstaw czego leżałaby „duchowość misyjna” (EG 15. 18. 27. 78-80)4.

Ewangelizacja widziana jest maksymalnie szeroko i głęboko, zgodnie z często przytaczanym przez papieża kryterium „całości, która przewyższa część" - radosna Nowina ma dotrzeć do każdego i dosięgnąć

1 W Elektronicznej Bibliografii Nauk Teologicznych FIDES można, co prawda, wyszukać artykuły poruszające niektóre kwestie (np. miłosierdzie, ubodzy, ewangelizacja czy ekologia), nie ma jednak tekstów dotyczących wizji teologii w ujęciu Ojca Świętego - por. http://biblio.fides.org.pl (data dostępu: 2018.11.10).

2 Franciszek, Konst. Apost. O uniwersytetach i wydziałach kościelnych Veritatis gaudium [dalej cyt. VG].

3 VG 1.3; idem, Adh. Apost. Evangelii gaudium, 1.17 [dalej cyt. EG]; idem, Przemówienie do uczestników sesji plenarnej Papieskiej Rady ds. Krzewienia Nowej Ewangelizacji Kościót jest narzędziem mitosierdzia (29.09.2017). Erygowanie zależnych od Kościoła uniwersytetów i wydziałów wiąże się z powierzonym przez Chrystusa posługą ewangelizowania - por. VG, Cz. I. - Przepisy ogólne, Tytuł I, Art. 1.

$4 \quad$ Franciszek mówi o trzech rodzajach duchowości: misyjnej (adh. Evangelii gaudium), ekologicznej (adh. Laudato si') i życia rodzinnego, ew. rodziny (adh. Amoris laetitia)-GE 28. Por. J. Baker, Yes to Mission Spirituality, „International Review of Mission”, 104 (2015) nr 2, s. 393. 
wszystkich wymiarów człowieka, a także przeniknąć całą ludzką kulturę (EG 170.237; VG 25). Veritatis Gaudium idzie po linii wytyczonej przez Sapientia Christiana, która z kolei „chwytała” wskazówki soborowe rozwinięte potem w dokumentach Magisterium. Franciszek z uznaniem wypowiada się zwłaszcza o adhortacji Pawła VI poświęconej kwestii ewangelizacji w świecie współczesnym: mówi o proroczym natchnieniu papieskiej zachęty, w której uznaje największy dokument pastoralny, jaki do tej pory został napisany ${ }^{6}$.

„W tym rozległym i bezprecedensowym horyzoncie, który otwiera się przed nami", Franciszek wypatruje czterech podstawowych kryteriów „odnowienia i odrodzenia wkładu studiów kościelnych w Kościół wychodzący na misję" (VG 4). Pierwsze z nich to

kontemplacja i wprowadzenie duchowe, intelektualne i egzystencjalne w serce kerygmatu, to znaczy nieustannie nową i fascynującą radosną nowinę Ewangelii Jezusa, ,która coraz bardziej i doskonalej się ukonkretnia" w życiu Kościoła i ludzkości (VG 4a).

Pierwsze przepowiadanie pozostaje centralne nie tylko dla ewangelizacji, ale również na etapie formacji i dojrzewania (EG 160):

Gdy mówimy, że to orędzie jest „pierwsze”, nie oznacza to, że jest na początku, a potem się o nim zapomina, albo zastępuje się je innymi treściami, które je przewyższają. Jest pierwszym w sensie jakościowym, ponieważ jest głównym orędziem, tym, do którego trzeba stale powracać i słuchać na różne sposoby i które trzeba stale głosić podczas katechezy w tej czy innej formie, na wszystkich jej etapach i chwilach (EG $164^{7}$ ).

Theology of Pope Francis

Pierwsze orędzie dotyczy Kościoła jako całości, a w nim również rodzin jako „Kościołów domowych”, przed którymi, w których i przez które winno rozbrzmiewać ${ }^{8}$. Jednak w VG jest mowa o tym, że kerygma coraz lepiej ukonkretnia się również w ludzkości (por. EG 165). Franciszek wiąże to z misją Kościoła będącego sakramentem zbawienia ludzkości, Kościoła-misterium znajdującego swój historyczny wyraz właśnie w pielgrzymującym i ewangelizującym Ludzie Bożym (VG 4a). Wezwanie do wzrastania w wierze nie oznacza ani wyłącznie, ani

$5 \quad$ Por. Paweł VI, Adh. Apost. Evangelii nuntiandii, 17 [dalej cyt. EN].

$6 \quad$ VG2; idem, Discorso del Santo Padre Francesco ai partecipanti al pellegrinaggio della diocesi Brescia (22.06.2013). Por. K. Lemna, D.H. Delaney, Three Pathways into the Theological Mind of Pope Francis, „Nova et Vetera” (eng. edition) 2014 nr 1, s. 36.

7 Por. M. Olszewski, Preaching the Gospel..., „Rocznik Teologii Katolickiej” t. 15, 2016, nr 2, s. 154.

8 Franciszek, Adh. Apost. Amoris laetitia, 58. 184. 290 [dalej cyt. AL]. 
nawet priorytetowo formacji doktrynalnej, lecz coraz doskonalszą odpowiedź na miłość Chrystusa i Jego nowe przykazanie (por. J 15,12) (EG 161; AL 207).

Jeśli cały Kościół staje się „szpitalem polowym”, funkcja teologii zostaje podporządkowana misji Zbawienia i uzdrowienia. Papież podkreśla, że jeśli miłosierdzie jest centralną treścią Ewangelii i najistotniejszym wymiarem życia Kościoła, to różne dyscypliny teologii, od dogmatycznej, przez moralną, aż po duchowość, winny odzwierciedlać refleksję nad wiarą w Boga, który jest miłością?

\section{Społeczny wymiar}

W ramach szeroko pojętej ewangelizacji sytuuje się jej społeczny wymiar, bez którego misja głoszenia Dobrej Nowiny musi zostać zniekształcona. Ewangelizowanie to, zdaniem Ojca Świętego, czynienie obecnym Królestwa Bożego (EG 176), a treść społeczna wynika już z samej kerygmy, której przepowiadanie ma reperkusję w postaci miłości. Związek ten pozostaje nierozdzielny; nie daje się bowiem oddzielić Chrystusa od Królestwa, które on przyniósł i do szukania którego wezwał (por. Mt 6,33). Słowa Mistrza sugerują interpretować bliźnich jako przedłużenie Wcielenia (por. Mt 25,40), a stosunek do nich otrzymuje znamię transcendencji (EG 177. 179; GE 25. 100 ${ }^{10}$ ).

Chrystusowe odkupienie i działalność Ducha Świętego dotyczą nie

Theology of Pope Francis jedynie pojedynczych osób, ale również stosunków społecznych; nie da się Ewangelii zredukować do osobistej relacji z Bogiem, a wiary sprowadzić jedynie do wnętrza Kościoła, owszem wzywa ona do budowania nie tylko wiecznego miasta w zaświatach, ale i społeczności doczesnych, a w nich przestrzeni braterstwa, niemożliwych bez fundamentu wiary ${ }^{11}$ :

$9 \quad$ AL 291; Franciszek, Przemówienie podczas spotkania zuczestnikami Kongresu Kościoła we Włoszech Marzy mi się Kościół niespokojny (2015.11.10) [dalej cyt. MKN]; idem, List z okazji 100 rocznicy ustanowienia Wydziatu Teologicznego na „Pontificia Universidad Católica Argentina” (2015.03.03) [dalej cyt. L].

10 Por. Aparecida. V Ogólna Konferencja Episkopatów Ameryki Łacińskiej i Karaibów. Dokument Końcowy Jesteśmy uczniami i misjonarzami Jezusa Chrystusa, aby nasze narody miaty w Nim życie, 393-394 [dalej cyt. A]; K. Lemna, D.H. Delaney, art. cyt., s. 41.

11 EG 178. 180. 183; VG 4a; idem, Enc. Lumen fidei 51.54 [dalej cyt. LF]; idem, List apost. Misericordia et misera, 18 [dalej cyt. MM]; Papieska Rada Iustitia et Pax, Kompendium Nauki Społecznej Kościoła, 52. Papież miałby odrzucać zarówno pietyzm niezainteresowany społecznym wymiarem Ewangelii, jak i sekularyzm nieuznający roli Ewangelii w społecznej rzeczywistości - por. K. Himes, 
Z serca Ewangelii poznajemy wewnętrzną więź między ewangelizacją i promocją człowieka, która powinna z konieczności wyrazić się i umocnić w całej działalności ewangelizacyjnej. Przyjęcie pierwszego orędzia, zapraszającego do tego, byśmy pozwolili się kochać Bogu i kochali Go miłością, którą On nam komunikuje, wywołuje w życiu osoby i jej działaniach pierwszą i podstawową reakcję: pragnąć, szukać i mieć na sercu dobro innych (EG 178).

To dążenie jest wyrazem istoty i powołania Kościoła do misji, która obejmuje również czynną miłość bliźniego, ta zaś domaga się nieustannego exodusu. Jeśli Słowo stało się ciałem, również w relacji z braćmi nie wolno uciekać się do „niekonkretnej”, niewyrażającej się w uczynkach miłosierdzia miłości, byłoby to jakby poszukiwaniem Chrystusa czysto duchowego i odcieleśnianiem Kościoła (EG 88-89. 179; MM 14. 18-19 ${ }^{12}$ ). Kościół doświadczający „mistyki życia razem” stawać ma się zaczynem powszechnego braterstwa (VG4a; EG 87). Dla teologii oznacza to zadanie odkrywania „sieci relacji” w całym stworzeniu, w którym odbijają się ślady Trójcy Świętej, w celu formowania kultury inspirowanej wiarą chrześcijańską (VG4a).

Z całą mocą podkreśla Franciszek opcję na rzecz ubogich, która dla Kościoła jest kategorią przede wszystkim teologiczną, a zwłaszcza chrystologiczną. Preferencyjne miejsce dla ubogich wynika z faktu Wcielenia: Bóg w Chrystusie stał się ubogim (por. 2Kor 8,9), był zawsze blisko ostatnich i utożsamił się właśnie z najmniejszymi (por. Mt 25,3536). Z tego powodu Papież pragnie Kościoła ubogiego dla ubogich, brak troski, o których wręcz wyłącza z woli Ojca (por. 1J 3, 17). Zaś miłość bliźniego obejmuje także próby zaradzenia strukturalnym przyczynom Theology ubóstwa (EG 48. 186-188. 195. 197-198. 202. 209; GE 96; LS 158; MKN ${ }^{13}$ ). I właśnie ta preferencyjna opcja, oczekuje Ojciec Święty, „musi przeniknąć prezentację i pogłębienie prawdy chrześcijańskiej” (VG 4a).

\section{Towarzyszenie ludzkości}

Konstytucja VG wychodzi z założenia, że

Chapter Four of Evangelii Gaudium: The Social Dimension of Evangelization, „International Review of Mission” (2015) 401, s. 182.

12 Por. Franciszek, List miłosny (Msza św. w Domu św. Marty, 11.11.2016), https:// opoka.org.pl/biblioteka/W/WP/franciszek_i/homilie/swmarta_11112016.html (dostęp: 2018.09.28).

13 Por. A 391-398; Ch. Ilo, The Church of the Poor. Towards an Ecclesiology of Vulnerable Mission, „Ecclesiology” (2014) 10, s. 230. Również osobista świętość nie może pomijać niesprawiedliwości świata, a modlitwy nie wolno rozumieć jako ucieczki czy negacji świata - GE 101. 152. 
Lud Boży jest pielgrzymem na drogach dziejów, szczerze i solidarnie towarzysząc mężczyznom i kobietom wszystkich narodów i wszystkich kultur, aby światłem Ewangelii oświecić pielgrzymowanie ludzkości ku nowej cywilizacji miłości” (VG 1). W tych słowach daje się wychwycić echo bodaj jednego z najważniejszych dla Franciszka wytycznych Vaticanum Secundum zapisanych w pierwszych słowach Gaudium et spes ${ }^{14}$. Sobór „ukazał blask wiary w ludzkim doświadczeniu, przemierzając tym samym drogi współczesnego człowieka (LF 6).

W odwołaniu do darzonego niezwykłą estymą Pawła VI uznaje Franciszek Kościół za „służebnicę ludzkości”, która jak Samarytanin nie przestaje pochylać się nad ludzkością w imię religii Boga, który stał się człowiekiem, nawet gdy ludzkość ta propaguje świecki humanizm, czyli religię człowieka, który chce być Bogiem ${ }^{15}$. Ponieważ wiara nie oddala od świata, lecz głębiej w niego wszczepia (LF 51; AL 181), do misji ewangelizacyjnej Kościoła „wyruszającego w drogę” należy towarzyszenie ludzkości we wszelkich jej doświadczeniach oraz krzewienie integralnego rozwoju wszystkich ludzi i całego człowieka, w co wpisują się również studia kościelne (VG 1-2; EG 24).

Dlatego drugim kryterium odrodzenia studiów kościelnych jawi się Papieżowi dialog otwierający na wymianę darów, współdziałanie ze wszystkimi osobami o przekonaniach religijnych i humanistycznych, a także współpraca ze specjalistami z różnych dyscyplin naukowych. Wymaga się rewizji zarówno struktury, jak i dynamiki metodycznej

Theology of Pope Francis programu studiów kościelnych; dotyczy to tak źródeł teologicznych, jak i ewangelizacyjnej intencjonalności - celem jest dotarcie w te obszary, w których kształtują się nowe narracje i paradygmaty kulturowe (VG 4b; EG 74) $)^{16}$.

$\mathrm{Z}$ tego wynika trzecie Franciszkowe kryterium: transdyscyplinarność (coś więcej niż interdyscyplinarność) umiejscawiająca wszelką wiedzę w obrębie mądrości emanującej z Objawienia. Co eschatologicznie dane jest w Jezusie Chrystusie, w którym wszelkie skarby

14 Sobór Watykański II, Konstytucja duszpasterska o Kościele w świecie współczesnym Gaudium et spes, 1 [dalej cyt. GS].

15 Por. Franciszek, Discorso del Santo Padre Francesco ai partecipanti al pellegrinaggio della diocesi Brescia (22.06.2013), art. cyt.; G.L. Müller, Ubóstwo, tłum. S. Śledziewski, Lublin 2014, s. 108; A 135.

16 Oczywiście w całym tym procesie „należy starannie badać, wybierać i przyjmować pozytywne wartości znajdujące się w różnych filozofiach i kulturach; jednak nie można zaakceptować systemów i metod, których nie da się pogodzić z wiarą chrześcijańską" - VG, Część druga - Przepisy szczegółowe, Tyt. I, art. 71, par. 2. Przykładem krytyki starego i próbą tworzenia nowego paradygmatu jest encyklika społeczna Franciszka - por. Franciszek, Enc. Laudato si', 16. 53 [dalej cyt. LS]. 
mądrości i wiedzy się skrywają (por. Kol 2,3), w historii odsłania się $\mathrm{w}$ wielopostaciowym bogactwie rzeczywistości widzianej w świetle „zamysłu Chrystusa” (por. 1Kor 2,16). Przyszłość ofiarowana przez Zmartwychwstałego oddziałuje na teraźniejszość, wiara idąca z przeszłości i przyszłości oświetla historię. Studia kościelne miałyby służyć nie tyle integracji pokawałkowanej wiedzy, ile nadawać pewne ukierunkowanie przy poszanowaniu istniejących napięć (VG 2. 4c-d; LF 4. 57; LS 83. 99-100. 221. 235 ${ }^{17}$ ).

Związana jest $\mathrm{z}$ tym potrzeba tworzenia sieci międzyinstytucjonalnych wewnątrzkościelnych, współdziałania z instytucjami naukowymi inspirowanymi różnymi tradycjami kulturowymi i religijnymi, tworzenia specjalistycznych ośrodków badających i poszukujących rozwiązań problemów o znaczeniu epokowym (czwarte kryterium), tak by móc kierować nowymi zjawiskami i wykorzystywać je w służbie cywilizacji miłości. W ten sposób Kościół miałby się stać znakiem i narzędziem jednoczenia ludzkości z tajemnicą komunii Trójcy Świętej (VG 2. 4d. 5; EG 133-134; LS 62).

Wszystko to oznacza, że zadaniem wydziałów teologicznych jest nie tylko „wyjaśnianie, zgodnie z właściwą jej metodą, nauki katolickiej zaczerpniętej z największą troską z Bożego Objawienia”, ale również poszukiwanie „rzetelnych rozwiązań ludzkich problemów w świetle tegoż Objawienia" (VG, Część druga - Przepisy szczegółowe, Tyt. I, art. 69) oraz „przedstawianie ich ludziom współczesnym w sposób dostosowany do różnych kultur" (VG, Część pierwsza - Przepisy ogólne, Tytuł I, art. 3, par. 1). Kościół „wychodzący” domaga się, by studia kościelne stanowiły nie tylko miejsce formacji, ale również:

rodzaj opatrznościowego laboratorium kulturowego, w którym Kościół dokonuje performatywnej interpretacji rzeczywistości, która wypływa z wydarzenia Jezusa Chrystusa i która karmi się darami mądrości i wiedzy, jakimi Duch Święty ubogaca w różnych formach cały lud Boży: od sensus fidei fidelium do magisterium pasterzy, od charyzmatu proroków po charyzmat doktorów i teologów (VG 3).

Uczelnie kościelne będą mogły przysłużyć się na zasadzie ewangelicznej soli wypracowaniu nowej kultury umożliwiającej zmianę modelu globalnego rozwoju oraz redefinicję postępu. Chodzi o swego rodzaju „hermeneutykę ewangeliczną”, duchową atmosferę badań naukowych opartych na prawdach wiary i rozumu (VG 3; LS 114.

$17 \quad$ Wzorem odniesienie dla Franciszka jest nie kula (punkty równo oddalone od środka), lecz wielościan (wszelkie partykularyzmy zachowują swoją oryginalność) - EG 236; VG 4d; AL 4; idem, D. Wolton, Otwieranie drzwi. Rozmowy o Kościele i świecie, tłum. M. Chojnacki, Kraków 2018, s. 35-37. 254. 
194). Ewangelizacyjny wymiar wyrazi się w wypracowaniu nowych paradygmatów działania i myśli przydatnych do głoszenia w pluralistycznym świecie. Tak zwana oryginalna apologetyka to wchodzenie w dialog ze światem kultury i nauki tak, aby religia chrześcijańska była w świecie reprezentowana, nawet jeśli prawda Ewangelii miałaby być jedynie w niedoskonały sposób przekazywana (VG 5; EG 45. 132-134. 242).

\section{Poszerzone rozumienie ortodoksji}

\section{Żywa rzeka Tradycji}

W interpretacji Papieża Sobór przezwyciężył rozdźwięk na linii teologia-duszpasterstwo i zrewolucjonizował status teologii: spotkanie doktryny i pasterskiej troski staje się dla niej konstytutywne. Jeśli Vaticanum Secundum był ,aktualizacją” Ewangelii z perspektywy współczesnej kultury, uprawianie teologii sytuować się ma na pograniczu: teologia winna zaspokajać potrzeby ludzi, którym należy w sposób dla nich zrozumiały głosić Ewangelię. „Nauka wiary” miałaby uczyć jak najlepszej odpowiedzi na miłość Bożą, a służba Zbawieniu stanowić o jedności teorii i praktyki ${ }^{18}$.

Z rozróżnienia między istotą depozytu wiary a sposobem przedstawiania doktryny wynika konieczność rozeznawania, co należy

Theology of Pope Francis do treści przesłania, a co do kulturowo uwarunkowanych, a zatem zmiennych w czasie, form przekazu. Albo, od drugiej strony: rolą teologa jest właśnie odpowiadać na pytania czasu w sposób dostosowany do współczesnych ludzi, a nawet całych kultur. Ucieczka przed tym zadaniem równałaby się zdradzie treści wiadomości, i mogłaby prowadzić do przekazu fałszywego boga. Jeśli główną treścią Ewangelii jest żywy Chrystus ofiarowujący się ludziom „tu i teraz”, doktryna nie jest systemem zamkniętym, lecz pozostaje dynamicznie otwarta na tych, do których jest skierowana (V; VG 5; VG, Część druga-Przepisy szczegółowe, Tyt. I, art. 71, par. 1; EG 40. 133; MKN).

Ojciec Święty postuluje poważne potraktowanie tak Tradycji, jak i aktualnej rzeczywistości, i zmuszenie ich do dialogu. W ten sposób uniknie się dwóch pokus: z jednej strony, potępiania wszystkiego w imię rzekomo lepszej przeszłości oraz chronienia się w konserwatyzmie czy

18 UCA; GE 45; idem, Wideoprzestanie do uczestników Międzynarodowego Kongresu Teologicznego na „Pontificia Universidad Católica Argentina” (2015.09.01-03) [dalej cyt. V]; VG 2; Sobór Watykański II, Dekret o formacji kapłańskiej Optatam totius, 19 [dalej cyt. OT]. Por. R. Shields, A Disturbing Pope, Cardinal Newman, and the Voice of the Faithful, „Cross Currents” (2016) 4, s. 416. 
fundamentalizmie, z drugiej, odrzucenia przeszłości i relatywizowania dziedzictwa Kościoła na rzecz „konsekrowania” wszelkiej nowości. Niezastąpiona rola teologii polega na wytyczeniu „wąskiej ścieżki” między tymi skrajnościami (V).

Franciszek przywołuje obraz wykorzystany przez poprzednika: Tradycji jako żywej rzeki, w której zawsze obecne są źródła ${ }^{19}$. Jest to jednoznaczne opowiedzenie się za „hermeneutyką reformy” (by użyć sformułowania Benedykta XVI), przy czym obecny papież widzi „ciągłość” elastyczniej niż Papież-senior ${ }^{20}$. Żywa rzeka ma zasilać współczesną rzeczywistość (towarzysząc jej przełomom i konfliktom), wchodzić w kontakt z ludem (w interakcji, z którego życiem się interpretuje) oraz kulturami (w których staje się ciałem w nowy sposób). Przybieranie oblicza różnych kultur wyraża powszechność Kościoła oraz ukazuje nowe aspekty Objawienia. Katolickie znamię Kościoła domaga się uszanowania dialektycznej polaryzacji między tym, co partykularne a tym, co powszechne: wspólnota nie ma monopolu na inkulturację, a Kościół uniwersalny nie może ignorować lokalnego „wcielenia” Tradycji (V; VG 4-5; EG 115-116 ${ }^{21}$ ).

19 Tradycja w sensie teologicznym nie jest „,zwyczajnym materialnym przekazem tego, co w początkach zostało dane Apostołom, lecz skuteczną obecnością Pana Jezusa, ukrzyżowanego i zmartwychwstałego, który przewodzi i towarzyszy w Duchu zgromadzonej przez siebie wspólnocie. [...] Dzięki Tradycji, której rękojmią jest posługa Apostołów i ich następców, woda życia, która wypłynęła z boku Chrystusa, i Jego zbawcza Krew docierają do ludzi wszystkich czasów. I tak Tradycja to stała obecność Zbawiciela, który wychodzi nam na spotkanie, Theology of Pope Francis przychodzi nas odkupić i uświęcić w Duchu przez posługę Jego Kościoła, na chwałę Ojca. [...] Tradycja nie jest przekazem rzeczy lub słów, nie jest zbiorem rzeczy martwych. Tradycja to żywa rzeka, łącząca nas ze źródłem - żywa rzeka, w której źródło jest zawsze obecne. To wielka rzeka prowadząca nas do portu wieczności" - cyt. za: Benedykt XVI, Audiencja generalna Komunia w czasie - Tradycja (2006.04.26). Por. L. Feingold, Faith Comes From What is Heard. An Introduction to Fundamental Theology, Steubenville 2016, s. 215-217.

20 Por. Franciszek, D. Wolton, op. cit., s. 325: „Papież Benedykt powiedział bardzo wyraźnie: zmiany w Kościele należy przeprowadzać zgodnie z hermeneutyką ciągłości. Piękne zdanie. Hermeneutyka wzrasta: pewne rzeczy się zmieniają, ale zawsze w sposób ciągły. Nie zdradza swoich korzeni, ale je wyjaśnia, dzięki czemu jest lepiej rozumiana".

21 Por. Franciszek, Discorso alla Comunità della Pontificia Università Gregoriana e ai Consociati del Pontificio Istituto Biblico e del Pontificio Istituto Orientale (2014.04.10). Nie chodzi o statycznie rozumiane wcielenie kulturowe, ale o nieustanny proces. Dlatego Papież celebrując stulecie Wydziału Teologii w Argentynie wzywa do ponownego przemyślenia, w jaki sposób żywa rzeka Ewangelii zaspokaja dziś pragnienie ludu tego kraju - V. Por. Franciszek, D. Wolton, op. cit., s. 322-325. 


\section{Prymat ortodoksji egzystencjalnej}

Jedność wiary wg Franciszka zakorzenia się w fakcie Inkarnacji, której skutkiem jest stałe dzielenie historii Wcielonego z wierzącymi. Również Kościół jako jedno Ciało i jeden Duch wyznaje jedną wiarę (por. Ef 4, 4-5). Depozyt należy przekazywać w całej pełni $(1 \mathrm{Tm} 6$, 20) - ujęcie czegoś z wiary Kościoła zagroziłoby komunii eklezjalnej (LF 47-48). Należy jednak dostrzegać, że nexus mysteriorum pozostaje w służbie centralnego przepowiadania, dlatego papież soborową wytyczną o istnieniu „hierarchii” prawd wiary (hierarchia veritatum) wiąże z kerygmatem: niektóre z prawd wiary wyrażają istotę Ewangelii bardziej bezpośrednio. Trzeba ukazywać zarówno ich centralny charakter, jak i całość orędzia, w którym wszystkie tajemnice wiary wzajemnie się naświetlają (EG 36. 38-39. 42) ${ }^{22}$.

Przez swoje odniesienie do Boga wiara odznacza się wyższą jednością niż jedność możliwa do osiągnięcia ludzką myślą (LF 47) ${ }^{23}$. Jeśli otrzymaną od Pana wiarę pojmujemy i wyrażamy w sposób niedoskonały, należałoby zdaniem papieża dopuścić różnorodność interpretacji doktryny i życia chrześcijańskiego. Więcej nawet: dążenie do monolitycznej jedności zbliżałoby do postawy gnostyków, którzy szukali rzekomo wyższego rodzaju jedności (GE 40.43) ${ }^{24}$. Neognostyckie tendencje ujawniają się w utożsamieniu Objawienia z formą, jaką przybrała rozumowa artykulacja wiary, skutkiem czego wiara może

Theology of Pope Francis zostać podporządkowania zabsolutyzowanej teorii teologicznej lub stać się próbą zapanowania nad transcendentnym Bogiem (GE 39. 41. 46) ${ }^{25}$ :

Boga nie można sprowadzić do przedmiotu. On jest Podmiotem, który pozwala się poznać i objawia się w relacji osoby z osobą. [...] Cechą teologii jest zatem pokora, pozwala ona „dotknąć się” Bogu, uznaje swoje ograniczenia w obliczu Tajemnicy i stara się badać z dyscypliną właściwą rozumowi niezgłębione bogactwo tej Tajemnicy (LF 36).

22 Zasada hierarchii prawd wiary odgrywa również niebagatelną rolę w ekumenizmie - EG 246.

23 Por. Międzynarodowa Komisja Teologiczna, Jedność wiary i pluralizm teologiczny, nr 4.

$24 \quad$ Możliwość istnienia różnych interpretacji doktryny i działania wiąże Papież z zasadą „prymatu czasu nad przestrzenią" - AL 3. Gnostycy w niezgodzie na istnienie niemożliwych do pojęcia napięć poszukiwali wymuszonej jedności por. H. Urs von Balthasar, Wprowadzenie, [w:] Ireneusz z Lyonu, Bóg w ciele $i$ krwi, wyb. i oprac. H. Urs von Balthasar, tłum. W. Myszor, Kraków 2001, s. 11.

25 Por. Międzynarodowa Komisja Teologiczna, Teologia dzisiaj. Perspektywy, zasady i kryteria, nr 99: „w poszukiwaniu prawdziwej mądrości przez studium Tajemnicy Boga teologia uznaje całkowite pierwszeństwo Boga; chce nie tyle posiąść Boga, ile być przez Niego posiadaną". 
Franciszek uznaje relatywizm życiowy (praktyczny) za bardziej niebezpieczny od relatywizmu doktrynalnego (teoretycznego) (EG 80.194; LS 122). Nie oznacza to relatywizowania doktryny, lecz ustawienie jej w służbie wiernej Bogu drogi życia. Wiąże się to z ustawicznie przywoływanym przez Franciszka kryterium rzeczywistości ważniejszej od idei wyprowadzonego z kryterium Wcielenia Słowa (por. 1J 4,2). Jeśli ostateczną prawdą jest Wcielony, wtedy prawda nie może pozostawać ideą abstrakcyjną, musi zostać „wcielona” w rzeczywistość (VG 1; EG 231-233; LS 110. 201) ${ }^{26}$.

Chodzi nawet o coś więcej niż uznanie, że prawdziwym ortodoksem jest ortopraktyk żyjący wiarą ${ }^{27}$. Raczej rzecz w tym, że ortodoksja oznacza uczestnictwo wierzących $\mathrm{w}$ praxis $\mathrm{Boga}^{28}$, i tak rozumiana prawowierność ma być wiernością centralnemu przesłaniu Ewangelii. W związku z tym Ojciec Święty jako strażnik przekazanego depozytu wiary broni miłosierdzia, na którym opiera się życie Kościoła. Krytykującym go o „rozmywanie” wiary odpowiada, że najgorszym rozwadnianiem Ewangelii jest ogołocenie miłosierdzia z realnego sensu przez postawienie mu zbyt wielu warunków wynikających z przyjętej koncepcji teologicznej (AL 310-311; MM 1-2) ${ }^{29}$, albo przez takie ,zdoktrynizowanie" Ewangelii, które sprawia wrażenie porzucenia przez Kościół-Matkę (AL 49.59) ${ }^{30}$. Nie wzięcie pod uwagę konkretnej i ograniczonej rzeczywistości, a także czasu, w którym łaska działa stopniowo, mogłoby doprowadzić „ortodoksa” do pelagianizmu, kosztem rzeczywistego zorientowania się na ewangelizację i duszpasterstwo (GE 35. 50. 59; EG 94; AL 37).

Theology of Pope Francis

${ }_{26} \quad$ Por. AL 49. 59 oraz 36 (krytyka oderwanego od rzeczywistości ideału małżeńskiego); J.C. Scannone, Pope Francis and the Theology of the People, „Theological Studies” (2016) nr 1, s. 129. Jak ważna jest ta zasada „wcielenia” dla papieża widać w tym, że nawet wielkich zasad katolickiej nauki społecznej nie chce on pozostawiać jedynie ogólnymi wskazaniami, ale oczekuje wyciągnięcia z nich praktycznych wniosków dotyczących konkretnych sytuacji - EG 182.

$27 \quad$ Por. C. Sedmak, Kościót ubogich. Papież Franciszek i transformacja ortodoksji, tłum. D. Chabrajska, Warszawa 2018, s. 69: „Konotacją ortodoksji jest właściwa relacja z Bogiem. W ortodoksji chodzi o to, by żywić prawą wiarę, wiara bowiem dotyczy przede wszystkim jakości relacji, nie zaś jakości sytuacji poznawczej człowieka".

28 Zgodnie z poglądem Gerharda Ludwiga Müllera - por. T. Rowland, Catholic Theology, London-Oxford-New York-New Delhi-Sydney 2017, s. 190-191.

29 Por. Franciszek, D. Wolton, op. cit., s. 222-223.

30 Konsekwentnie, jeśli powołaniem Kościoła jest być otwartym domem Ojca, nie może to nie znaleźć konkretnego wyrazu w dostępie do sakramentów - EG 47 oraz: AL 305, przypis nr 351; MM 14. 


\section{Źródła teologiczne}

Ojciec Święty powtarza soborowe wytyczne mówiące o tym, że studium Pisma Świętego winno być duszą teologii, przy czym badanie to winno się łączyć z uczestnictwem w liturgii świętej będącej źródłem chrześcijańskiego ducha, a także ze studiowaniem żywej Tradycji Kościoła w dialogu z dzisiejszymi ludźmi. Właśnie i jedynie dzięki temu powiązaniu jest możliwe odsłanianie się w umyśle misterium Chrystusa żywego, działającego na Kościół i całą ludzkość (VG 2; OT 16 ${ }^{31}$ ).

Franciszek baczy zarówno na to, by miecz Słowa nie został stępiony (por. Hbr 4,12), jak i na to, by słodycz Słowa nie została utracona (por. Ps 119,103), a przesłanie tekstu - rozwodnione. Dlatego, mimo iż docenia wartość zasad interpretacyjnych, to jednak, zwłaszcza w kontekście miłosierdzia, przedkłada przyjmowanie Słowa sine glossa nad komentarzami odbierającymi mu moc (GE 97. 156; EG 150. 153) ${ }^{32}$. Kontakt z Jezusem w Piśmie Świętym prowadzi do przemieniającego spotkania z Jezusem w Eucharystii (GE 157). Wyrazi się ona dbałością o członków Ciała Chrystusa, „rozpoznaniem” Ciała Pańskiego tak w znakach sakramentalnych, jak i we wspólnocie (por. 1Kor 11,29) (AL 185-186) ${ }^{33}$. Również w tym wypadku bezpośrednich wskazań Ewangelii nie wolno „pacyfikować” czy to „kościelną hermeneutyką”, czy też „aparatami pojęciowymi", które winny ułatwiać kontakt z rzeczywistością, a nie oddalać od niej (EG 194; GE 109; MM 20) ${ }^{34}$.

Theology of Pope Francis
31 Por. A 323, gdzie podkreśla się, że Słowo Boże w formacji seminaryjnej ma stawać się duchem i życiem karmiącym całą egzystencję.

32 Wprost odwołuje się Franciszek do analizy literackiej (trzeba dojść do tego, co hagiograf zamierzał przekazać, bo bez tego Słowo byłoby wystawione na ryzyko przystosowania do własnych korzyści czy schematów myślowych) i egzegezy kanonicznej (ale uprawianej w taki sposób, by dana perykopa nie traciła swojego specyficznego wydźwięku, gdy zostanie ukazana na tle całości Pisma) - EG 147-148.

33 Dodatkowej mocy nabiera ta papieska wypowiedź przez to, że została wyrażona w orędziu skierowanym do rodzin: „Gdy osoby przyjmujące Komunię św. nie dają się pobudzić do zaangażowania względem ubogich i cierpiących lub zgadzają się na różne formy podziału, pogardy i niesprawiedliwości, to Eucharystia przyjmowana jest niegodnie. Natomiast rodziny, które przyjmują Eucharystię z właściwą dyspozycją, umacniają swoje pragnienie braterstwa, swój sens społeczny i zaangażowanie na rzecz potrzebujących" - AL 186. Por. Benedykt XVI, Enc. Deus caritas est, 14 - o społecznym charakterze mistyki sakramentu Eucharystii. Franciszek podkreśla, że w całym życiu sakramentalnym jest udzielane miłosierdzie Boże - MM 5. 8. 14.

34 Por. Międzynarodowa Komisja Teologiczna, Nadzieja zbawienia dla dzieci, które umieraja bez chrztu, nr 2. Papież podkreśla, że chrześcijański kult musi 
W kontekście głoszenia Słowa (por. (EG 146-152) pojawia się drugie miejsce teologiczne: Lud Boży, czy szerzej: rzeczywistość, w której ludzie żyją. Co prawda, poniższe słowa wypowiedziane zostały do kaznodziejów, ale dotyczą one także, jak o tym świadczy całokształt papieskich zapatrywań, teologów: „Kaznodzieja jest człowiekiem kontemplującym Słowo, a także kontemplującym lud" (EG 154) ${ }^{35}$. Ten sam Duch, który natchnął hagiografów, działa w wiernych i inspiruje do słuchania Ludu (EG 139). Dzięki powiązaniu z ich sytuacją i wydarzeniami będzie można odczytać Boże wezwanie i wprowadzić Ewangelię w życie ludu i potrzeby historii (EG 95-96. 154-155; V; EN 43. 63).

Temat relacji teologii i Ludu Bożego pojawił się wprost w przesłaniu do argentyńskich teologów. Ojciec Święty stwierdził, że doktryna nie jest systemem zamkniętym, owszem pytania, wątpliwości, cierpienia i zmagania ludu mają wartość interpretacyjną, i to „proroctwo braci” ze względu na poważne potraktowanie zasady Wcielenia nie może być ignorowane. Uprawiający teologię winien wejść wzorem Wcielonego $\mathrm{w}$ komunię z ludźmi i w kontakt $\mathrm{z}$ ich realnym życiem. Jezus już jest na ulicach Argentyny ratując ludzi i dlatego tam, wśród nich, trzeba Go szukać. „Nauka wiary”, która nie narodziła się w łonie Ludu, może być piękna, ale nie jest prawdziwa (V; GE 44; EG 97).

Podkreśla się związek następcy św. Piotra z tzw. teología del pueblo ${ }^{36}$, choć sam Papież nie przepadał za tym terminem ${ }^{37}$. Punktem wyjścia „teologii ludu” stała się analiza kulturowo-historyczna widziana w świetle wiary ${ }^{38}$. Juan Carlos Scannone, największy adwokat argentyńskiej teologii wyzwolenia, a przy okazji mentor Ojca Świętego, Theology of Pope podkreślał, że religia wiernego Ludu Bożego, pewnego rodzaju mądrościowe poznanie, jest kluczowym miejscem teologicznej refleksji3i ${ }^{39}$. Również Franciszek za dokumentem z Aparecidy będzie pisał o duchowości czy mistyce ludowej (EG 124. 237; A 263), a w pobożności ludowej dostrzegał efekt inkulturacji Ewangelii, a zarazem podmiot

wyrażać się w poświęceniu braciom, a modlitwa winna przekształcać życie w świetle miłosierdzia - GE 104-106.

35 Franciszek mówi o kontemplowaniu oblicza Jezusa(MKN) oraz kontemplowaniu bliźniego (EG 169).

Por. T. Rowland, op. cit., s. 192.

37 Por. Franciszek, D. Wolton, op. cit., s. 48. 271. Według papieża „teologia ludu” to teologia Kościoła jako Ludu Bożego - por. ibidem, s. 270.

38 Por. K. Lemna, D.H. Delaney, art. cyt., s. 26-27. Ten punkt wyjścia nie oznacza „socjologizowania”, ponieważ analiza rzeczywistości jest już lekturą czytaną w perspektywie wiary - por. G.L. Müller, op. cit., s. 126.

39 Por. J.C. Scannone, s. 123; K. Lemna, D.H. Delaney, op. cit., s. 31-32. 
ewangelizacji całych kultur. Poprawnie odczytana pobożność ludowa staje się miejscem teologicznym ważnym, zwłaszcza w dobie nowej ewangelizacji (EG 69. 90. 122-124. 126 ${ }^{40}$ ).

W ramach Ludu Bożego uprzywilejowane miejsce zajmują ubodzy. Sami w sobie stają się oni locus theologicus, ponieważ mają wyjątkowy dostęp do Chrystusa:

Oprócz uczestnictwa w sensus fidei, dzięki własnym cierpieniom znają Chrystusa cierpiącego. Jest rzeczą konieczną, abyśmy wszyscy pozwolili się przez nich ewangelizować. Nowa ewangelizacja jest zaproszeniem do uznania zbawczej mocy ich egzystencji i do postawienia jej w centrum drogi Kościoła. Jesteśmy wezwani do [...] przyjęcia tajemniczej mądrości, którą Bóg chce nam przekazać przez nich (EG 19841).

Zmysł wiary pozwala rozeznawać, co rzeczywiście pochodzi od Boga i obdarza cały lud mądrością w pojmowaniu Bożej rzeczywistości intuicyjnie. Węch owczarni pozwala jej rozpoznawać nowe drogi, co powinno zostać uwzględnione przez pasterzy (EG 31. 119). Sam Franciszek, co niektórzy mu zarzucają, w swoich refleksjach posługuje się chętniej niż teologicznymi refleksjami tym „nadprzyrodzonym instynktem”42, z którym wiąże się „ewangeliczne rozeznanie” (EG 50).

W świetle wypowiedzi papieskich za szczególnie ważny locus - zresztą pozostający nie bez związku z poprzednimi źródłami - należałoby uznać „,znaki czasu”. Wydarzenia, procesy i zjawiska, w których można

Theology of Pope Francis dopatrzeć się ingerencji Ducha Świętego działającego w ludzkości, domagają się konfrontacji z Ewangelią, a zadanie ich interpretacji stojące przed Kościołem dotyczy szczególnie pasterzy i teologów ${ }^{43}$. Zdaniem Franciszka, wspólnotowe wsłuchiwanie się w Ducha Świętego pozwala rozpoznać signa temporis, co jest ważne dla procesu ewangelizacji oraz humanizacji ludzkości (EG 14. 51. 108 ${ }^{44}$ ). Rozeznawanie zakłada „nie tylko uznanie oraz interpretowanie poruszeń dobrego ducha i złego

$40 \quad$ Nie oznacza to bezkrytycznego stanowiska, owszem należy rozróżnić między sentymentalną dewocją a autentyczną pobożnością ludową - EG 70.

${ }_{41}$ Por. M. Tomaszewski, Błogosławieni ubodzy. Teologia w stuzbie wyzwolenia, [w:] Kościół Franciszka, red. P. Artemiuk, Płock 2014, s. 53-54.

42 Por. Międzynarodowa Komisja Teologiczna, „Sensus fidei” w życiu Kościoła, 44. 54.

$43 \quad$ Por. GS 4. 11. 44; D. Adamczyk, Rozpoznawanie znaków czasu w perspektywie wezwania Jezusa do ewangelizacji, „Ruch Biblijny i Liturgiczny” (2008) nr 4, s. 286.

44 Za jeden ze znaków czasu uznaje Franciszek migracje - AL 46. Waga znaków czasu została już mocno podkreślona w Aparecidzie - por. A 33. 
ducha, lecz - i to jest decydujące - wybranie poruszeń dobrego ducha i odrzucenie tych pochodzących od ducha złego" (EG $51^{45}$ ).

\section{Perspektywy dalszych badań}

1. Umiejscowienie wiary poszukującej zrozumienia w ramach służby przepowiadania prowokuje refleksje metateologiczne. Co miałoby oznaczać dla teologii jej kerygmatyczne zorientowanie? Jak uprawiać teologię zorientowaną na centralne przesłanie Ewangelii, jakim jest miłosierdzie, bez sprowadzenia „nauki wiary” do jedynie użytecznego narzędzia w rękach pasterzy? Na pewno wciąż jest wiele do zrobienia $\mathrm{w}$ kwestii poszukiwania syntezy teologii i podejścia pastoralnego ${ }^{46}$, co winno zostać poprzedzone metanamysłem nad związkiem logosu z etosem. Zdaniem Ojca Świętego, chrześcijaństwo o tyle jest przedmiotem refleksji, o ile lepiej pomaga żyć Ewangelią (GE 109). Czy miałoby to oznaczać uznanie „nauki wiary” za naukę praktyczną ${ }^{47}$ ? Czy może Franciszek , jedynie” zaprasza do wyjścia teologów ze szklanego zamku na ulicę, by przesiąknąć zapachem ludzi (UCA; L)? Przykład przywoływanej przez Papieża myśli Romano Guardiniego ${ }^{48}$ może tu rzucić wiele światła - obstawał on za prymatem logosu przed etosem, a za podstawowe zadanie uniwersytetu uważał poszukiwanie prawdy dla niej samej ${ }^{49}$.

Z opcją ewangelizacyjną wiążą się też zagadnienia warte podjęcia przez teologów duchowości we współpracy z teologami

$45 \quad$ W kwestii rozeznawania, co pochodzi od Ducha Świętego, a co od złego ducha lub z ducha tego świata: nie chodzi jedynie o posłużenie się rozumowaniem czy skorzystanie z ,gotowej” mądrości Kościoła, ale o dar pochodzący od Ducha Świętego pielęgnowany przez modlitwę, refleksję, lekturę, słuchanie Boga, ludzi oraz samej rzeczywistości. Tego rodzaju łaska rozeznawania jest ważna, zwłaszcza w obliczu pojawiających się nowości, przy rozpoznawaniu czasu Bożej łaski oraz czytaniu znaków czasu - GE 166. 168-172.

46 Por. nieco hiperbolizującą ocenę dzisiejszego stanu rzeczy [w:] R. Shields, op. cit., s. 414: „This inner-ecclesiastical debate looks more like a confrontation between a "pastoral approach», on the one hand, and «unalterable Catholic teachings» on the other, than a fraternal dialogue".

47 Scientia fidei za Tomaszem z Akwinu jest rozumiana jako nauka jednocześnie teoretyczna i praktyczna, jednak bardziej teoretyczna. Dopiero teologia, która jest scientia speculativa, może stawać się scientia practica - por. L. Feingold, op. cit., s. 127-130; J. Ratzinger, Wiara $w$ Piśmie i Tradycji. Teologiczna nauka o zasadach (Opera omnia, t. IX/1), tłum. J. Merecki, Lublin 2018, s. 259.

48 Bergoglio pracował nad doktoratem dotyczącym teologii Romano Guardiniego - por. K. Lemna, D.H. Delaney, art. cyt., s. 26.

$49 \quad$ Por. J. Ratzinger, op. cit., s. 117. 258. 
systematycznymi. Ci ostatni mogliby przebadać teologiczny fundament dla „duchowości misyjnej”. Chodziłoby o taki kształt życia chrześcijańskiego, który budowałby się wokół ewangelizacyjnego centrum ${ }^{50}$, zamiast skupiania się jedynie na wewnętrznych przeżyciach, co byłoby trudne do pogodzenia z logiką Wcielenia oraz wymogami miłosierdzia ${ }^{51}$. Prawdziwa pobożność, jak najdalsza od „,bezcielesności” (przestrogi Franciszka przed gnostycyzmem), łączyłaby życie wewnętrzne z zewnętrznym zaangażowaniem: „ponieważ kontemplacja, która zaniedbuje innych, jest oszustwem" (EG 281).

Ojciec Święty ewangelizację łączy z czynieniem Królestwa Bożego, co jest rozumiane jako zaangażowanie społeczne. Teologia winna tutaj poszukiwać głębszej jedności, a zarazem rozróżnienia między eschatologicznym Królestwem Bożym a wartościami tego Królestwa możliwymi do zrealizowania w doczesności. Wkład teologii wyzwolenia w Kościół powszechny wolno interpretować jako zwrócenie uwagi na nierozdzielność eschatologii i historii, transcendencji i immanencji, oraz potrzebę odrzucania wszelkich dualizmów oddzielających ostatecznie Boga i świat ${ }^{52}$. Z kolei jednak należy wystrzegać się monistycznego utożsamienia postępu doczesnego i Królestwa Bożego, na co zwracała uwagę Międzynarodowa Komisja Teologiczna. Przede wszystkim trzeba podkreślać, że wzrost Królestwa Bożego nie dokonuje się nigdy poza misterium Krzyża, a to oznacza, że nie wolno go

Theology of Pope Francis redukować do praxis odnawiającej porządek społeczny i polityczny. Jeśli Franciszek podkreśla, że wiary nie można sprowadzać do budowania wiecznego miasta $\mathrm{w}$ zaświatach, to $\mathrm{z}$ kolei należy uszanować różnicę między miastem ziemskim i niebieskim ${ }^{53}$.

W kluczowych dla tego pontyfikatu słowach Gaudium et spes mówi się o ścisłej łączności między Kościołem a współczesnymi ludźmi i ich doświadczeniami, którym wspólnota wierzących przedstawia orędzie Zbawienia (nr 1). Zgodnie z założeniami teologii ludu, istnieje owocna wymiana między Ludem Bożym a ludźmi, którym Ewangelia oraz

50 Życie duchowe dzięki realnemu kontaktowi ze środowiskiem niewiary pozwoliłoby uniknąć zagrożenia uciekania od rzeczywistości w stronę pobożnych idei - por. M. Delbrêl, Radość wiary, tłum. D. Salik, Kraków 2008, s. 185, 188, 189.

$51 \quad$ EG 262, w którym Papież cytuje poprzednika - por. Jan Paweł II, List apost. Novo millenio ineunte, 52.

52 Por. G.L. Müller, op. cit., s. 34. 59-60. 62; T. Rowland, op. cit., s. 203.

53 Por. Międzynarodowa Komisja Teologiczna, Postęp ludzki i zbawienie chrześcijańskie, 2, A; 4, b. 
Kościół i jego społeczne nauczanie ma wiele do powiedzenia ${ }^{54}$. Lektura VG ukazuje Kościół jako oświetlający drogi ludzkości, bez oczekiwania od współczesnych nawrócenia. Jak to się ma do ewangelizacyjnego programu? Czy kerygmat miałby być skierowany przede wszystkim do samych wierzących, a ewangelizacyjna rola względem niewierzących sprowadzona do bycia samarytaninem ludzkości? Czy Papież nie nazbyt optymistycznie zakłada, że Ukrzyżowany i Zmartwychwstały, Pan całych dziejów, oraz Jego Duch, działają tajemniczo i zwycięsko w całym świecie i historii (VG 6; EG 278)? Czy dopuszcza się tu myśl o świecie wprost sprzeciwiającym się Chrystusowi? A co z działaniem złego ducha, przed którego wpływem przestrzegał Franciszek w GE? Czy miałby on bardziej działać w życiu osobistym i Kościele niż we współczesnym świecie? I w końcu: czy posoborowe doświadczenia nie każą zweryfikować relacji między Kościołem a światem?

2. Rysuje się w wypowiedziach papieskich problem między nienaruszalnością wyznawanej doktryny a integralnością realizowanego przesłania Ewangelii ${ }^{55}$. Wyłania się pytanie o to, na ile teologiczne rozumienie fidei depositum adekwatnie wyraża istotę Ewangelii. $\mathrm{Na}$ pewno zaś nie popadając $\mathrm{w}$ błąd doktrynalny można mijać się $\mathrm{z}$ wolą Bożą ${ }^{56}$. Interesującą uwagę poczynił w związku z tym Clemens Sedmak, według którego otwiera się tu droga do szerszego rozumienia ortodoksji - chodziłoby o związek ortodoksji pierwszego rzędu (wierność nauczaniu Kościoła) z ortodoksją drugiego rzędu (bycie uczniem Chrystusa w oparciu o przyjęcie ortodoksji pierwszego rzędu), przy czym Theology of Pope ortodoksji egzystencjalnej (podstawowe ukierunkowanie w oparciu o Ewangelię) w pewnej mierze przysługiwać miałoby pierwszeństwo ${ }^{57}$.

54 Por. K. Lemna, D.H. Delaney, art. cyt., s. 42. Według Scannone’a ewangelizacja kultur dokonuje się na zasadzie „cudownej wymiany” między Ludem Bożym a ludźmi, przy czym w procesie tym pośredniczy pobożność wiernych - por. ibidem, s. 35 .

55 Jak podkreśla australijski teolog, Franciszek próbuje utrzymać dwa centralne przekonania: z jednej strony, pełny ideał i obiektywne nauczenie Kościoła, z drugiej strony, realne znaczenie miłosierdzia jako istotnego przesłania Ewangelii w konkretnej rzeczywistości - por. G. O'Collins, The Joy of Love (Amoris Laetitia). The Papal Exhortation in Its Context, „Theological Studies” (2016) nr 4, s. 920. Por. również: J.F. Keenan, Receiving Amoris Laetitia, „Theological Studies" (2017) 1, s. 194-195.

56 Ojciec Święty wręcz mówi o dwóch logikach: panujących w Kościele: logice integracji opartej na uprzedzającej miłości miłosiernej Boga oraz logice wykluczania, która często podpiera się doktryną jak prawem - AL. 296. 299. 312; MM 11; Otwieranie drzwi..., s. 142.

57 Por. C. Sedmak, op. cit., s. 26-27. 242. 271. 299. 
Kolejnym zagadnieniem jawi się „otwartość” doktryny. Wypowiedzi papieskie w temacie rozróżnienia istoty od sformułowań wiary chrześcijańskiej Papież zdaje się traktować jako coś innego niż aggiornamento rozumiane jako „dostosowanie” gotowej doktryny do współczesności. Chodzi bardziej o wzajemną relację między wiarą a rzeczywistością, we wzajemnej interakcji których rodzą się sformułowania wiary. Temat ten wymaga pogłębienia.

Jeśli chodzi o loci theologici, największe zainteresowanie winien wzbudzić epistemologiczny status ubóstwa ${ }^{58}$. Scannone utrzymuje, że teologie wyzwolenia czynią z preferencyjnej opcji na rzecz ubogich punkt wyjścia i główny locus interpretacji ${ }^{59}$. Papież nie idzie tak daleko, ale rzeczywiście utrzymuje, że ubodzy znają Chrystusa w uprzywilejowany sposób, a przez to zdolni są „nauczać” również teologów ${ }^{60}$. W związku z tym opcja na rzecz ubogich miałaby w oczekiwaniu Franciszka przeniknąć całą prawdę chrześcijańską, zapewne także teologię.

Podkreśla się istotną rolę Bergoglio w powstaniu dokumentu z Aparecidy $^{61}$, a co za tym idzie, suponuje, że pontyfikat jest próbą rozciągnięcia latynoamerykańskiej wizji Kościoła na cały Kościól. Wydaje się, że teologia powinna pozwolić sobie na coś znacznie więcej niż inspirację czy delikatną zmianę nastawienia, ale z drugiej strony winna również wypracować konieczne rozróżnienia między tym, co dopuszczalne na zasadzie pluralizmu teologicznego a tym, co obowiązujące dla całej teologii ${ }^{2}$. Również trzeba by pytać, na ile teologia wyzwolenia stanowi

Theology of Pope Francis pozytywny impuls dla całej teologii, a na ile należy raczej podkreślać jej ograniczenia? Kwestia ta wymagałaby zbadania, zwłaszcza w kontekście często podkreślanego przez Papieża dialektycznego stosunku między Kościołem powszechnym a lokalnymi.

$58 \quad$ Sedmak wyraża przekonanie o poznawczym charakterze ubóstwa, które będzie miało konsekwencje dla pojmowania ortodoksji. Opcja na rzecz ubogich pozwoli rozpoznać pytania, które do tej pory przeoczano i ukaże nowe perspektywy, z których można by uprawiać teologię - por. Kościót ubogich..., s. 27. 165. 231.

J.C. Scannone, op. cit., s. 133.

Oczywiście nawet dla teologii wyzwolenia preferencyjna opcja nie może być interpretowana na sposób wykluczający. Ubodzy, jeśli są sercem Ludu Bożego, winni być widziany z perspektywy eklezjologii komunii - por. A 392; K. Lemna, D.H. Delaney, s. 33. 38-39.

1 Franciszek zwał przesłanie Aparecidy „Evangelii nuntiandi Ameryki Łacińskiej" - por. Otwieranie drzwi, s. 416.

Scannone wskazuje, że jakakolwiek inkulturowana teologia, jeśli ma być prawomocna, musi być zarazem uniwersalną teologią, ale skrywa się tu problem trudnej do utrzymania równowagi - por. K. Lemna, D.H. Delaney, op. cit., s. 32. 


\section{WIZJA TEOLOGII W WYPOWIEDZIACH PAPIEŻA FRANCISZKA}

Ojciec Święty nie stroni od tematów, które winny zainteresować teologów. W konstytucji apostolskiej Veritatis gaudium wyraził on wprost swoje rozumienie roli teologii na obecnym etapie misji Kościoła. Autor artykułu uszeregował wypowiedzi Franciszka w kontekście ewangelizacji rozumianej szeroko: od głoszenia kerygmatu, przez wymiar społeczny Ewangelii, aż po służbę towarzyszenia całej ludzkości. Następnie zaprezentowane zostało: papieskie rozumienie Tradycji w jej związku z rzeczywistością współczesną, ortodoksji nierozdzielnej od ortopraksji, a w końcu miejsc teologicznych (loci theologici). $\mathrm{Na}$ zakończenie autor zasugerował najważniejsze kwestie, które domagają się dalszych badań teologicznych. Wśród nich zasługuje na uwagę zwłaszcza sprawa pogłębionego pojmowania ortodoksji.

Słowa kluczowe: papież Franciszek, ortodoksja, ortopraksja, teologia, ewangelizacja, argentyńska teologia wyzwolenia, loci theologici, Tradycja, opcja na rzecz ubogich, Veritatis gaudium.

\section{Bibliografia:}

1. Aparecida. V Ogólna Konferencja Episkopatów Ameryki Łacińskiej i Karaibów. Dokument Końcowy Jesteśmy uczniami i misjonarzami Jezusa Chrystusa, aby nasze narody miały w Nim życie, tłum. K. Zabawa, K. Łukoszczyk, Gubin 2014.

2. Adamczyk D., Rozpoznawanie znaków czasu $w$ perspektywie wezwania Jezusa do ewangelizacji, „Ruch biblijny i liturgiczny” (2008) nr 4, s. 279-296.

3. Baker J., Yes to Mission Spirituality, „International Review of Mission”, 104 (2015) nr 2, s. 393-402.

4. Balthasar H. Urs von, Wprowadzenie, [w:] Ireneusz z Lyonu, Bóg w ciele $i$ krwi, wyb. i oprac. H. Urs von Balthasar, tłum. W. Myszor, Kraków 2001, s. $5-16$.

5. Benedykt XVI, Audiencja generalna Komunia w czasie - Tradycja (2006.04.26), https://opoka.org.pl/biblioteka/W/WP/benedykt_xvi/audiencje/ag_26042006.html (dostęp: 2018.11.05).

6. Benedykt XVI, Enc. Deus caritas est.

7. Delbrêl M., Radość wiary, tłum. D. Salik, Kraków 2008.

8. Feingold L., Faith Comes From What is Heard. An Introduction to Fundamental Theology, Steubenville 2016.

9. Franciszek, Adh. Apost. Amoris laetitia.

10. Franciszek, Adh. Apost. Evangelii gaudium.

11. Franciszek, Wolton D., Otwieranie drzwi. Rozmowy o Kościele i świecie, tłum. M. Chojnacki, Kraków 2018.

12. Franciszek, Discorso alla Comunità della Pontificia Università Gregoriana e ai Consociati del Pontificio Istituto Biblico e del Pontificio Istituto Orientale (2014.04.10), https://w2.vatican.va/content/francesco/en/speeches/2014/ 
Theology of Pope Francis april/documents/papa-francesco_20140410_universita-consortium-gregorianum.html (dostęp: 2018.11.07).

13. Franciszek, Discorso del Santo Padre Francesco ai partecipanti al pellegrinaggio della diocesi Brescia (22.06.2013), http://w2.vatican.va/content/ francesco/it/speeches/2013/june/documents/papa-francesco_20130622_pellegrinaggio-diocesi-brescia.html (dostęp: 2018.09.28).

14. Franciszek, Enc. Laudato si'.

15. Franciszek, Enc. Lumen fidei.

16. Franciszek, Konst. Apost. O uniwersytetach i wydziałach kościelnych Veritatis gaudium, http://w2.vatican.va/content/francesco/pl/apost_constitutions/documents/papa-francesco_costituzione-ap_20171208_veritatis-gaudium.html (dostęp: 2018.07.14).

17. Franciszek, List apost. Misericordia et misera.

18. Franciszek, List miłosny (Msza św. w Domu św. Marty, 2016.11.11), https:// opoka.org.pl/biblioteka/W/WP/franciszek_i/homilie/swmarta 11112016. html (dostęp: 2018.09.28).

19. Franciszek, List z okazji 100 rocznicy ustanowienia Wydziatu Teologicznego na „Pontificia Universidad Católica Argentina” (2015.03.03), https:// w2.vatican.va/content/francesco/it/letters/2015/documents/papa-francesco_20150303_lettera-universita-cattolica-argentina.html (dostęp: 2018.11.03).

20. Franciszek, Przemówienie do uczestników sesji plenarnej Papieskiej Rady ds. Krzewienia Nowej Ewangelizacji Kościót jest narzędziem miłosierdzia (29.09.2017), https://opoka.org.pl/biblioteka/W/WP/franciszek_i/przemowienia/ewangelizacja_29092017.html (dostęp: 2018.07.14).

21. Franciszek, Przemówienie podczas spotkania z uczestnikami Kongresu Kościoła we Włoszech Marzy mi się Kościót niespokojny (2015.11.10), https://opoka.org.pl/biblioteka/W/WP/franciszek_i/przemowienia/kongres_kosciola_10112015.html (dostęp: 2018.10.28).

22. Franciszek, Wideoprzestanie do uczestników Międzynarodowego Kongresu Teologicznego na „Pontificia Universidad Católica Argentina” (2015.09.0103), https://w2.vatican.va/content/francesco/it/messages/pont-messages/2015/documents/papa-francesco_20150903_videomessaggio-teologia-buenos-aires.html (dostęp: 2018.09.28).

23. Himes K., Chapter Four of Evangelii Gaudium: The Social Dimension of Evangelization, „International Review of Mission” (2015) 401, s. 181-186.

24. Ilo Ch., The Church of the Poor. Towards an Ecclesiology of Vulnerable Mission, „Ecclesiology” (2014) 10, s. 229-250.

25. Jan Paweł II, List apost. Novo millenio ineunte.

26. Keenan J.F., Receiving Amoris Laetitia, „Theological Studies” 78 (2017) 1, s. 193-212.

27. Lemna K., Delaney D.H., Three Pathways into the Theological Mind of Pope Francis, „Nova et Vetera” (eng. edition) (2014) nr 1, s. 25-56.

28. Międzynarodowa Komisja Teologiczna, „Sensus fidei” $w \dot{z} y c i u$ Kościoła. Dokument Międzynarodowej Komisji Teologicznej (2014), tłum. M. Moskal, Kraków 2015. 
29. Międzynarodowa Komisja Teologiczna, Jedność wiary i pluralizm teologiczny (1972), tłum. J. Królikowski, [w:] Od wiary do teologii. Dokumenty Międzynarodowej Komisji Teologicznej 1969-1996, red. J. Królikowski, Kraków 2000, s. 15-18.

30. Międzynarodowa Komisja Teologiczna, Nadzieja zbawienia dla dzieci, które umieraja bez chrztu (2007), tłum. J. Królikowski, Kraków 2008.

31. Międzynarodowa Komisja Teologiczna, Postęp ludzki i zbawienie chrześcijańskie (1976), tłum. J. Królikowski, [w:] Od wiary do teologii. Dokumenty Międzynarodowej Komisji Teologicznej 1969-1996, red. J. Królikowski, Kraków 2000, s. 71-88.

32. Międzynarodowa Komisja Teologiczna, Teologia dzisiaj. Perspektywy, zasady i kryteria (2012), tłum. K. Stopa, Kraków 2012.

33. Müller G.L., Ubóstwo, tłum. S. Śledziewski, Lublin 2014.

34. O'Collins G., The Joy of Love (Amoris Laetitia). The Papal Exhortation in Its Context, „Theological Studies” 74 (2016) nr 4, s. 905-921.

35. Olszewski M., Preaching the Gospel..., „Rocznik Teologii Katolickiej” (2016) nr 2, s. 149-159.

36. Papieska Rada Iustitia et Pax, Kompendium Nauki Społecznej Kościoła, tłum. D. Chodyniecki i in., Kielce 2005.

37. Paweł VI, Adh. Apost. Evangelii nuntiandii.

38. Ratzinger J., Wiara $w$ Piśmie $i$ Tradycji. Teologiczna nauka o zasadach (Opera omnia, t. IX/1), tłum. J. Merecki, Lublin 2018.

39. Rowland T., Catholic Theology, London-Oxford-New York-New DelhiSydney 2017.

40. Scannone J.C., Pope Francis and the Theology of the People, „Theological Studies" (2016) nr 1, s. 118-135.

41. Sedmak C., Kościót ubogich. Papież Franciszek i transformacja ortodoksji, Theology tłum. D. Chabrajska, Warszawa 2018.

42. Shields R., A Disturbing Pope, Cardinal Newman, and the Voice of the Francis Faithful, „Cross Currents” (2016) 4, s. 414-429.

43. Sobór Watykański II, Dekret o formacji kapłańskiej Optatam totius, [w:] Sobór Watykański II, Konstytucje, dekrety, deklaracje. Tekst polski. Nowe ttumaczenie, Poznań 2002, s. 288-301.

44. Sobór Watykański II, Konstytucja duszpasterska o Kościele w świecie współczesnym Gaudium et spes, [w:] Sobór Watykański II, Konstytucje, dekrety, deklaracje. Tekst polski. Nowe ttumaczenie, Poznań 2002, s. 526-606.

45. Tomaszewski M., Błogostawieni ubodzy. Teologia w stużbie wyzwolenia, [w:] Kościót Franciszka, red. P. Artemiuk, Płock 2014, s. 43-56. 